Pierwsza wersja złożona 20.03.2016

Ostatnia wersja zaakceptowana 11.06.2016
ISSN (print) 1689-8966

ISSN (online) 2450-7040

Marta Przybylska*

\title{
UMIEJĘTNOŚCI KIEROWNICZE POTRZEBNE KIEROWNIKOM W XXI WIEKU
}

Z a r y s t r e ś c i: Przedmiotem rozważań są umiejętności kierownicze kierowników potrzebne do zarządzania organizacją w XXI wieku. Szczególną uwagę zwrócono na uniwersalizm umiejętności kierowniczych pomimo tego, że zostały one wykreowane w różnych okresach i w odmiennej kulturze. W artykule zostały zaprezentowane najważniejsze umiejętności kierownicze, które powinni posiadać kierownicy przedsiębiorstw w XXI wieku, aby móc sprawnie i efektywnie zarządzać organizacjami w ówczesnych czasach.

S ł o w a k 1 u c z o w e: umiejętności, kierownik, umiejętności kierownicze, XXI wiek, zarządzać, przedsiębiorstwo, organizacja, menedżer.

K 1 a s y fik a c j J E L: L21

\section{WSTĘP}

Każdy kierownik, aby móc sprawnie i efektywnie zarządzać przedsiębiorstwem powinien potrafić planować, organizować, motywować swoich podwładnych oraz kontrolować wszystkie procesy zachodzące w organizacji, nie zważając na ich wielkość czy złożoność. [Stoner i Wankel, 1994, s. 35] Kierownicy powinni zarządzać organizacją z rozwagą, a także, tak aby nie narażać jej na niepotrzebne ryzyko. [Penc, 2000, s. 54] Jednak im przedsiębiorstwo jest większe, bardziej złożone, tym kierownik ma mniej czasu, aby móc kontrolować wszystkie te obszary, dlatego ważną rolę odgrywają umiejętności kierowników w przedsiębiorstwach. Dzięki nim kadra kierownicza może delegować wszystkie czynności, procesy zachodzące w organizacji. [Stoner i Wankel, 1994, s. 35] Podstawowa definicja umiejętności kierowniczych to „względnie trwała zdolność do zastosowania profesjonalnej wiedzy w sposób praktyczny, w celu uzyskania pożądanego rezultatu w danej sytuacji

Adres do korespondencji: Marta Przybylska, Uniwersytet Ekonomiczny w Poznaniu, Wydział Zarządzania, Katedra Teorii i Organizacji Zarządzania, al. Niepodległości 10, 61-875 Poznań, e-mail: marta.przybylska993@gmail.com. 
działania" [Penc, 2005, s. 66].

Umiejętności kierownicze istnieją od wielu lat. Pomimo tego, iż sytuacja na świecie, na rynku niejednokrotnie uległa zmianie, to i tak większość umiejętności kierowniczych powstałych kilkadziesiąt lat temu nadal jest aktualna $\mathrm{i}$ potrzebna menadżerom w XXI, aby móc sprawnie zarządzać organizacją.

Celem artykułu jest przedstawienie niezbędnych umiejętności kierowników, którzy zarządzają organizacją w XXI wieku. Problemem badawczym jest próba odpowiedzi na pytanie, czy umiejętności kierownicze powstałe w poprzednim stuleciu są użyteczne dla kierowników XXI wieku podczas procesu zarządzania przedsiębiorstwem?

\section{UMIEJĘTNOŚCI KIEROWNICZE NA PODSTAWIE MODELU R. KATZ'A}

Jako pierwszy wyrażenie umiejętności kierownicze użył R. Katz w swoim modelu. Był on akademickim nauczycielem, a także przemysłowcem. R. Katz podzielił umiejętności kierownicze na trzy kategorie: techniczne, społeczne oraz koncepcyjne. [Stoner i Wankel, 1994, s. 35]

Umiejętność techniczna ,jest to zdolność posługiwania się narzędziami, metodami i technologią w określonej specjalności" [Stoner i Wankel, 1994, s. 36]. Na umiejętność techniczną składa się: prowadzenie działalności gospodarczej, dbanie o kondycję przedsiębiorstwa oraz zdobywanie środków finansowych. Umiejętności te, umożliwiają kierownikom nienaganne zarządzanie w organizacji. Umiejętność techniczna, o której pisał R. Katz w 1955 roku jest nadal współcześnie używana przez kierowników w przedsiębiorstwach, bowiem obserwuje się w nich coraz większą złożoność procesów produkcji oraz komputeryzacji obsługi. [Penc, 2001, s. 81]

Umiejętność techniczna to umiejętność najprostsza, ponieważ kierownicy mogą ją nabyć dzięki edukacji w specjalistycznych dziedzinach, a także poprzez doświadczenie, które zdobywają przez lata ciężkiej pracy. [Rakowska i Sitko-Lutek, 2000, s. 19] Często w organizacjach XXI wieku używany jest podział kierowników według obszarów zarządzania. Najczęstsze wykorzystywane podziały to: marketing, finanse, eksploatacja (operacja), zasoby ludzkie, administracja, i inne dziedziny. We wszystkich tych działach potrzebna jest umiejętność techniczna, która pozwala na przykład: na ustalanie nowych działań promocyjnych (obszar marketingu), pozyskanie środków finansowych (obszar finansów), tworzenie nowych produktów (obszar operacja). Umiejętność techniczna stanowi pierwowzór umiejętności kierowniczych, które ukierunkowane są na ciągłe pogłębianie wiedzy. Kierownicy w XXI wieku powinni cały czas się uczyć, dokształcać, dlatego też umiejętność techniczna jest jak najbardziej potrzebna w 
XXI wieku. [Bartkowiak i Januszek, 1999, s. 145 - 146]

Następną umiejętnością zawartą w modelu R. Katza, którą menadżerowie XXI wieku wykorzystują to umiejętność społeczna. Jest to ,zdolność współpracowania z innymi ludźmi, rozumienia ich i motywowania, zarówno poszczególnych osób, jak i grup” [Stoner i Wankel, 1994, s. 36] oraz „upraszczania komunikacji i zwiększania jej efektywności, [...], sprawiedliwego oceniania pracowników, współpracy z dostawcami, klientami, inwestorami i innymi partnerami spoza organizacji” [Penc, 2001, s. 81]. Kierownikom potrzebna jest ta umiejętność w celu nawiązania współpracy przede wszystkim z podwładnymi. Każdy pracownik w organizacji powinien doskonale wiedzieć, komu podlega oraz kto wydaje mu w pracy polecenia. Menadżerowie powinni zdołać zmotywować swoich pracowników do realizacji celów przedsiębiorstwa w sposób sprawny, efektywny. Dobry przywódca powinien również zadbać, o to aby sposób komunikowania się w przedsiębiorstwie był szybki, a także żeby żadne przekazywane wiadomości nie ulegały deformacji.

Umiejętność społeczna nadal jest umiejętnością potrzebną menadżerom $\mathrm{w}$ procesie zarządzania przedsiębiorstwem $\mathrm{w}$ XXI wieku. Tworzy ona grupę najbardziej pożądanych umiejętności, ponieważ w XXI wieku znaczną część przedsiębiorstw stanowią przedsiębiorstwa usługowe, które skupiają się przede wszystkim na kontakcie z drugą osobą. [Penc, 2001, s. 81]. Udział przedsiębiorstw usługowych w ogólnej liczbie przedsiębiorstw w Polsce w roku 2000 wynosił 74,69\%; w 2005 roku 77,03\%; a w 2008 roku wynosił 76,05\%. [Klóska R., Metody ilościowe w analizie struktury podmiotowej sektora usług w Polsce] Przedsiębiorstwa usługowe stanowią ponad trzy czwarte wszystkich przedsiębiorstw. Oznacza to, że umiejętność społeczna jest potrzebną umiejętnością kierowniczą w XXI wieku.

Ostatnia wyróżniona umiejętność przez R. Katz w swoim modelu to umiejętność koncepcyjna. Jest to „umysłowa zdolność koordynacji oraz integrowania wszystkich interesów i działalności organizacji. Jest to zdolność postrzegania organizacji, jako całość i współzależności jej części, a także zrozumienia, w jaki sposób zmiana w dowolnej części organizacji wpłynie na całość" [Stoner i Wankel, 1994, s. 36] To przede wszystkim umiejętność „lateralnego myślenia, rozpoznawania struktury sytuacji i współzależności czynników ją kształtujących, strategicznego myślenia i działania, horyzontalnego patrzenia na cele organizacji, formułowanie jej wizji i misji” [Penc, 2001, s. 81]. Dzięki tym umiejętnościom kierownik będzie w stanie zauważyć i wyodrębnić związki pomiędzy różnymi częściami, działami przedsiębiorstwa. Dzięki temu wdrożone przez niego działania, decyzje będą najlepsze dla przedsiębiorstwa. [Stoner i Wankel, 1994, s. 36]. Umiejętność koncepcyjna jest pomocna kierownikom podczas ustalania strategii oraz celów organizacji na okres teraźniejszy oraz przyszły. Umiejętność koncepcyjna należy do trudniejszych umiejętności, które są potrzebne kie- 
rownikom, aby mogli oni sprawnie zarządzać organizacją w XXI wieku. Kadra kierownicza oprócz zdobytej wiedzy i doświadczeniu powinna posiadać również intuicje, zdolności analityczne oraz dysponować szczegółowymi informacjami o rynku i konkurencji, na którym funkcjonuje przedsiębiorstwo.

Menadżerowie posiadający wszystkie umiejętności wymienione powyżej, dysponują umiejętnością koncepcyjną, dzięki której mogą zarządzać przedsiębiorstwem nie narażając go na ryzyko. W XXI wieku, aby przedsiębiorstwo mogło mieć przewagę nad konkurencją potrzebne są nieustanne analizy, przetwarzanie danych, dlatego też umiejętność koncepcyjna jest wymagana u kierowników w XXI wieku.

Zdaniem R. Katza połączenie umiejętności technicznych, społecznych oraz koncepcyjnych umożliwi kadrze kierowniczej sprawne, bezbłędne, efektywne zarządzanie organizacją. Pomimo tego, iż model R. Katza powstał w połowie XX wieku i jest bardzo często uważany za zbyt ogólny oraz za bardzo uproszczony to zawiera on umiejętności, które kierownicy w XXI wieku wciąż wykorzystują podczas zarządzania przedsiębiorstwem. [Rakowska i Sitko-Lutek, 2000, s. 20]

\section{UMIEJĘTNOŚCI KIEROWNICZE NA PODSTAWIE MODELU D. WHETTEN'A I K. CAMERON'A}

R. Katz jako pierwszy w swoim modelu użył wyrażenia umiejętności kierownicze oraz dokonał ich podziału na trzy grupy. Model ten niejednokrotnie został skrytykowany przez specjalistów, jednakże umiejętności opisane w nim są nadal wykorzystywane przez menadżerów XXI w przedsiębiorstwach, chociaż został on nazwany modelem wyjściowym.

Twórcy innego podziału umiejętności kierowniczych - D. Whetten i K. Camerona wzorowali się głównie na pierwowzorze modelu umiejętności kierowniczych R. Katza. Był on ich inspiracją do stworzenia własnego, ulepszonego, bardziej szczegółowego podziału umiejętności kierowniczych. Stwierdzili oni bowiem, że „menadżerowie zamiast uczyć się, jak należy kierować, uczą się teorii zarządzania" [za: Cameron i Whetten, Rakowska i Sitko-Lutek, 2000, s. 22]. D. Whetten i K. Cameron opracowali model, który miał na celu powiększenie umiejętności menadżerów $\mathrm{w}$ różnych obszarach zarządzania przedsiębiorstwem. Zdaniem twórców modelu bardzo ważne dla kierowników powinno być posiadanie dobrze rozwiniętych umiejętności interpersonalnych, a także dobrze rozwiniętych umiejętności kierowania sobą. Model ten zawiera przede wszystkim umiejętności, które można zdobyć w działaniu, a dopiero potem odtworzyć je w przedsiębiorstwie. [Rakowska i Sitko-Lutek, 2000, s. 22]

Umiejętności osobiste według twórców modelu są „niezbędne do zrozu- 
mienia własnych zachowań i emocji, do poznania samego siebie" [Rakowska i Sitko-Lutek, 2000, s. 22]. Umiejętności osobiste zostały podzielone przez D. Whettena i K. Camerona na trzy rodzaje umiejętności. Pierwszą umiejętnością osobistą jest rozwijanie samoświadomości, która koncentruje się na doskonaleniu kompetencji definiowania własnych wartości i priorytetów, umiejętności diagnozy swojego stylu poznawczego, sposobów zdobywania wiedzy oraz przełożenia ich na praktykę. [Rakowska i Sitko-Lutek, 2000, s. 22 - 23] Następną umiejętnością, która należy do umiejętności osobistych jest umiejętność twórczego rozwiązywania problemów. Jest to umiejętność, która polega na kreatywnym podejściu do różnych problemów i sytuacji w przedsiębiorstwie, a nie na książkowych, monotematycznych rozwiązaniach. Ostatnią umiejętnością osobistą jest umiejętność kierowania stresem, która polega na „radzeniu sobie ze stresem, identyfikowania stresorów oraz ich eliminowania, umiejętności redukowania napięcia" [Rakowska i Sitko-Lutek, 2000, s. 23]. Kierowanie stresem to także wyznaczanie przez kierowników swoich celów osobistych oraz zawodowych, tak aby były one możliwe do realizacji, spełniania. Umiejętności osobiste umożliwiają kadrze kierowniczej poznanie własnych możliwości, słabości, zachowań oraz emocji jakie towarzyszą w codziennej pracy. Zarządzanie przedsiębiorstwem należy do trudnych zadań, tylko kierownik o silnej osobowości jest w stanie podołać temu zadaniu.

Umiejętności osobiste to umiejętności, które menadżerowie używają w XXI wieku. Umiejętności te pomagają kierownikom rozwijać nie tylko przedsiębiorstwo, ale również swoje zdolności osobiste, osobowość. W ówczesnych czasach zarządzanie organizacją wymaga od menadżerów silnej osobowości oraz wiedzy, która umożliwi rozwój przedsiębiorstwa. Umiejętności osobiste cały czas ewoluują z powodu zmieniającego się sposobu życia społeczeństwa, kultury, dlatego też menadżerowie w XXI wieku potrzebują dodatkowych umiejętności osobistych, które nie zostały jeszcze zawarte w modelu D. Whetten'a i K. Cameron'a XX wieku.

Umiejętności interpersonalne, należą do tych umiejętności, które występują w bezpośrednich kontaktach z innymi osobami. D. Whetten oraz K. Cameron podzielili umiejętności interpersonalne na sześć rodzajów umiejętności interpersonalnych. Pierwszą umiejętnością jest ustanawianie wspierającej komunikacji. Zdolność ta charakteryzuje się efektywnym słuchaniem i mówieniem. Polega ona na dwustronnej komunikacji w przedsiębiorstwie. Kolejną umiejętnością w tej grupie jest umiejętność doskonalenia swoich podwładnych. Opiera się ona na kreowaniu wśród pracowników oczekiwanych przez kierowników zachowań oraz udzielaniu im cennych porad, aby mieli oni możliwość ciągłego doskonalenia się. [Rakowska i Sitko-Lutek, 2000, s. 24] Trzecią umiejętnością jest zdobywanie władzy i wpływu. Polega ona na zdobyciu przez kierowników uznania i szacunku u własnych podwładnych oraz wykorzystanie go dla ce- 
lów przedsiębiorstwa na przykład w celu maksymalizacji jego wartości. Ważna jest również identyfikacja nieformalnych źródeł władzy. Odróżnianie wpływu od władzy oraz należyte spożytkowanie zdobytej władzy. Czwartą umiejętnością należącą do umiejętności interpersonalnych jest zwiększanie motywacji podwładnych i nieustanne motywowanie ich. Jej celem jest wzrost wydajności przedsiębiorstwa dzięki maksymalnemu wykorzystaniu potencjału pracowników dzięki bezbłędnego wykorzystania procesu motywacyjnego przez kadrę kierowniczą, a także dzięki poznaniu pragnień swoich podwładnych. Piątą umiejętnością jest skuteczne delegowanie, które „polega na określeniu, jakie zadania, komu i kiedy, jak delegować, na określeniu stopnia nadzoru w trakcie realizacji i przydzielaniu uprawnień do wykonania zadania" [Rakowska i Sitko-Lutek, 2000, s. 24]. Nie posiadanie przez kierownika umiejętności delegowania zadań staje się przyczyną ich niskiej wydajności oraz efektywności. Kadra kierownicza powinna dobrze rozdzielać obowiązki wśród swoich podwładnych, tak aby każdy pracownik był dobrze poinformowany, co powinien zrobić, oraz aby jego zadanie nie wybiegało ponad jego umiejętności. Ostatnia umiejętność to umiejętność usprawnienia grupowego podejmowania decyzji. Polega ona na przeprowadzaniu przez kierowników zebrań, szkoleń, spotkań integracyjnych. [Rakowska i Sitko-Lutek, 2000, s. 24 - 25]

Po raz pierwszy umiejętność interpersonalną scharakteryzował R. Katz w 1955 roku w swoim modelu nazywając ją umiejętnością społeczną. D. Whetten i K. Cameron rozszerzyli ją o szerszy zakres kompetencji. Pomimo tego, że niektóre z tych umiejętności wydają się oczywiste i niepotrzebne kierownikom w XXI wieku, tak jak umiejętność zdobywania władzy i wpływu, to są to umiejętności na bieżąco używane przez managerów. Na niektóre umiejętności interpersonalnych kadra kierownicza nie zwraca uwagi podczas codziennego procesu zarządzania organizacją, a odgrywają one znaczącą role w sukcesach przedsiębiorstwa. Umiejętności interpersonalne D. Whetten'a i K. Cameron'a są aktualne i potrzebne kierownikom, którzy zarządzają przedsiębiorstwem w XXI wieku. Menadżerowie coraz większy nacisk kładą na poprawną komunikację w organizacji, dzięki której zwiększa się efektywność organizacji. Z czasem umiejętności interpersonalne D. Whetten'a i K. Cameron'a będą rozszerzać się o nowe kompetencje, dla których staną się silnym i stabilnym fundamentem do dalszego rozwoju.

Umiejętności zawarte w modelu D. Whetten'a i K. Cameron'a są jak najbardziej pomocne i potrzebne kierownikom w XXI wieku, ponieważ kładą one przede wszystkim nacisk na kształtowanie zachowań oraz relacji kierowników $\mathrm{z}$ ich podwładnymi, które w ówczesnych czasach są bardzo ważne w sprawnym zarządzaniu organizacją. 


\section{UMIEJĘTNOŚCI KIEROWNICZE CHARAKTERYSTYCZNE DLA XXI WIEKU}

W modelu D. Whettena i K. Camerona zostały przedstawione umiejętności kierownicze, które również powinni posiadać kierownicy w XXI wieku. Z ich pomocą jest możliwe efektywne zarządzanie przedsiębiorstwem.

Kierownicy zarządzający organizacjami w XXI działają w burzliwym, a także w niestabilnym otoczeniu. Dlatego też, kadra kierownicza każdego dnia zmaga się z coraz to bardziej złożonymi wyzwaniami. Bardzo ważne jest, aby kierownicy zdobywali coraz to nowsze umiejętności kierownicze, które umożliwią im rozwiązywanie problemów jakie istnieją w przedsiębiorstwach, ale jednocześnie żeby nie zapominali o umiejętnościach wcześniej zdobytych, opanowanych. [Witkowski, Listwan (red.), 2008, s. 415]

W XXI wieku zakłada się, że kierownik na rynku pracy będzie posiadał nie tylko umiejętności techniczne. Sytuacja ekonomiczna, polityczna i społeczna w XXI wieku ukształtowały nowe potrzebne umiejętności kierownicze, które kierownicy potrzebują, aby móc sprawnie zarządzać przedsiębiorstwem. Jedną z najważniejszych umiejętności potrzebnych kierownikowi w XXI wieku jest umiejętność pracy w zespole. W dzisiejszych czasach organizacje skupione są przede wszystkim na pracy zespołowej, uważają, że dzięki temu jest lepsza efektywność przedsiębiorstwa. [Pająk i Zduniak, 2003, s. 176 - 177] Kierownicy powinni poprawnie oceniać przede wszystkim z ilu osób ma składać się zespół - optymalna liczba to od 4 do 6 osób. Główną cechą zespołu jest współpraca, wspólne myślenie, a także wspólne podejmowanie decyzji. Osoby będące w jednym zespole nie powinny „toczyć” walki o wpływy. Ważne jest, aby, kierownicy potrafili stworzyć zespół z takich osób, których kompetencje, kwalifikacje dopełniają się, a nie są konkurencją. Umiejętność pracy w zespole dla kierowników jest umiejętnością skomplikowaną, stanowiącą problem z doborem odpowiednich pracowników, a także problem bycia „na równi” $\mathrm{z}$ innymi pracownikami przedsiębiorstwa w trakcie trwania projektu. [Kowalczyk, 2014, s. $140-143]$

S. Tokarski w swojej książce „Kierownik w organizacji” opisał umiejętności charakterystyczne dla kierowników XXI wieku. Według niego najważniejszą umiejętnością jest umiejętność pracy i postępowania z ludźmi. Polega ona przede wszystkim na zidentyfikowaniu potrzeb drugiej osoby, czyli podwładnych, co ich motywuje do pracy lub o czym myślą. Wykształceni i doświadczeni kierownicy, powinni umiejętnie dobierać instrumenty motywacyjne dla każdego pracownika z osobna. Na umiejętność pracy i postępowania $z$ ludźmi składa się również umiejętność określania celów dla przedsiębiorstwa. Istotne jest, aby były one przede wszystkim osiągalne, proste, mierzalne, realne i określone w czasie. Umiejętność doboru odpowiednich zachowań to kolejna 
umiejętność składająca się na umiejętność pracy i postępowania z ludźmi. W przedsiębiorstwach funkcjonujących w XXI wieku często mają miejsce sytuacje, gdzie potrzeby kierownika kłócą się z potrzebami pracowników. Dlatego też, kierownicy mają do wyboru trzy warianty: zostanie kierownikiem agresywnym, ustępliwym, czy też kierownikiem, który doskonale zna swoją wartość. Kolejną umiejętnością składającą się na umiejętność pracy i postępowania z ludźmi jest umiejętność panowania nad swoimi zachowaniami. Kierownicy nie powinni „wybuchać” ze złości przed swoimi podwładnymi. Stanowią oni pewien wzorzec do naśladowania dla pracowników, dlatego też powinni unikać wszelkich sytuacji, które mogłyby przeszkodzić w zdobywaniu celów organizacji. Kierownicy bezustannie powinni trenować swoje zachowanie wobec podwładnych. Piąta i ostatnia umiejętność, która składa się na umiejętność pracy postępowania z ludźmi to kształtowanie zachowań innych osób. Dzięki tej umiejętności kadra kierownicza umożliwia pracownikom: poszukiwanie koncepcji, pokazywanie możliwości jakie im daje przedsiębiorstwo, dostarczanie informacji, przejawianie sprzeciwu, popierania innego zdania. Kierownicy w XXI wieku powinni również profesjonalnie przeprowadzać rozmowę z podwładnymi. Ważne jest, aby w trakcie trwania rozmowy zawsze miał miejsce kontakt wzrokowy, właściwa gestykulacja, a także odpowiednia mowa ciała. Te trzy wymienione czynniki składają się na sukces oraz potwierdzają u kierowników posiadanie przez nich umiejętności pracy i postępowania z ludźmi w XXI wieku. [Tokarski, 2006, s. $71-78]$

Wymienione powyżej umiejętności należą do grupy umiejętności miękkich, które „koncentrują się na zachowaniu człowieka, postawach, sposobie bytowania. Dotyczą przede wszystkim zarządzania własną osobą, motywacji oraz umiejętności interpersonalnych" [http://www.nieparzekawy.pl/baza-wiedzy/kompetencje-twarde-i-miekkie---co-to jest.html].

Umiejętności kierownicze ukształtowane i rozszerzane w XXI wieku to nie tylko umiejętności miękkie, skupiające się przede wszystkim na pracy zespołowej i efektywnym sposobie komunikowania się. W XXI wieku zostały również wykształcone umiejętności, które dotyczą organizacji zwinnej. Organizacja zwinna to: „umiejętność wykorzystania pojawiających się okazji dzięki takim cechom przedsiębiorstwa jak bystrość, elastyczność, inteligencja i spryt”. [Trzcieliński, 2011, s. 11] Aby kierownicy mogli zarządzać organizacją zwinną powinni posiadać umiejętność myślenia innowacyjnego. Innowacyjność jest to możliwość i zdolność organizacji do rozwoju i adaptowania nowych i ulepszonych produktów, czy też świadczonych usług. [Janasz i Kozioł, 2007, s. 57] Dzięki umiejętnościom innowacyjnym kierowników przedsiębiorstwo ma możliwość ciągłego, nieustannego rozwoju, który umożliwia mu zostanie liderem na swoim rynku zbytu. Natomiast elastyczność to umiejętność dostosowywania przedsiębiorstwa do panujących sytuacji na rynku. Każdy kierownik zarządza- 
jący przedsiębiorstwem w XXI wieku, powinien szybko i umiejętnie reagować na zachodzące zmiany, tak aby organizacja jak najwięcej na tym zyskała. Posiadanie tych umiejętności może oznaczać, że przedsiębiorstwo zarządzane przez kadrę kierowniczą jest organizacją zwinną. Umiejętności te, są typowe dla kierowników, którzy zarządzają organizacją w XXI wieku. [Sajdak, 2013, s. $71-75]$

Umiejętności kierownicze charakterystyczne dla XXI wieku, skupiają się na tak zwanych ,umiejętnościach miękkich” oraz na modelu organizacji zwinnej. Początek XXI wieku to przede wszystkim rozwój internetu i nowych kanałów sprzedaży, promocji i reklamy. Nowe sposoby komunikacji z klientami i pracownikami wymusiły rozszerzenie umiejętności interpersonalnych, osobistych z XX wieku o nowe umiejętności dotyczące komunikacji międzyludzkiej. Dlatego też w XXI wieku największą uwagę skupia się na umiejętności pracy zespołowej, umiejętności postępowania z ludźmi oraz doboru odpowiednich zachowań. W XXI wieku znaczącą rolę odgrywają również umiejętności kierowników należących do organizacji zwinnych. Dzięki nim jest możliwość szybkiego dostosowania przedsiębiorstw do nowych sytuacji i tworzenia nowych innowacyjnych produktów, które zagwarantują przedsiębiorstwu pozycje lidera na rynku. Wszystkie wymienione umiejętności w rozdziale trzecim „stoją” na fundamentach umiejętności kierowniczych zbudowanych w XX wieku.

\section{PODSUMOWANIE}

Kadra kierownicza najwyższego szczebla odpowiedzialna jest za zarządzanie całym przedsiębiorstwem. Do ich obowiązków należą: uchwalanie polityki operacyjnej, prowadzenie wzajemnych oddziaływań przedsiębiorstwa i jego otoczenia. [Cyfert i Krzakiewicz, 2006, s. 28] Aby kierownicy mogli wykonać te wszystkie zadania prawidłowo potrzebne są im umiejętności kierownicze.

Celem artykułu było przedstawienie niezbędnych umiejętności kierowników, którzy zarządzają organizacją w XXI wieku. Umiejętności kierownicze, które zostały ukształtowane w poprzednim stuleciu nadal są aktualne i potrzebne kierownikom w XXI wieku. Niektóre z nich stanowią solidny fundament do dalszego rozwoju umiejętności charakterystycznych dla XXI wieku na przykład umiejętności interpersonalne. Kierownicy nie powinni zaprzestawać wykorzystywać umiejętności, które zostały wykreowane w XX wieku. Sytuacja na rynku, czy też sposób życia społeczeństwa cały czas ewoluuje, dlatego też kadra kierownicza powinna być przygotowana na zmiany, aby móc szybko na nie reagować i dostosowywać się do nich.

Począwszy od umiejętności kierowniczych zaprezentowanych przez R. Katz’a kończąc na umiejętnościach kierowniczych ukształtowanych w XXI wieku możliwe jest zaobserwowanie ich uniwersalizmu, powszechności. Mimo 
upływu lat wszystkie te umiejętności kierownicze są wciąż aktualne oraz użyteczne dla kierowników, którzy zarządzają przedsiębiorstwem w XXI wieku.

\section{LITERATURA}

Barkowiak G. i Januszek H., (1999), Umiejętności kierownicze , Akademia Ekonomiczna w Poznaniu, Poznań.

Cyfert Sz., Krzakiewicz K., (2006), Organizacja i zarzadzanie - przegląd podstawowych pojęć, [w:] Krzakiewicz K. (red.), Teoretyczne podstawy organizacji i zarzadzania, Akademia Ekonomiczna w Poznaniu, Poznań.

Janasz W., Kozioł K., (2007) Determinanty działalności innowacyjnej przedsiębiorstw, Polskie Wydawnictwo Ekonomiczne, Warszawa.

Klóska R., (2010) Metody ilościowe w analizie struktury podmiotowej sektora ustug w Polsce, [w:] Niematerialne i społeczne uwarunkowania funkcjonowania i rozwoju przedsiębiorstw (red.) A. Antonowicz, Wydział Zarządzania Uniwersytetu Gdańskiego, Gdańsk.

Kowalczyk E., (2014), Człowiek Organizacja Kariera Siła Psychologii Stosowanej, Difin, Warszawa.

Nogalski B., Śniadecki J., (2001), Umiejętności menadżerskie w zarządzaniu przedsiębiorstwem, Oficyna Wydawnicza Ośrodka Postępu Organizacyjnego Sp.z.o.o (OPO), Bydgoszcz.

Pająk Z., Zduniak A., (2003), Kierownik w XXI wieku determinanty psychospołeczne sukcesu, Dom Wydawniczy ELIPSA, Warszawa - Poznań.

Penc J., (2000), Kreatywne kierowanie organizacja i kierownik jutra rozwiązywanie problemów kadrowych, Agencja Wydawnicza PLACET, Warszawa.

Penc J., (2001), Decyzje menadżerskie - o sztuce zarządzania, C.H. Beck, Warszawa.

Penc J., (2005), Role i umiejętności menadżerskie. Sekrety sukcesu i kariery, Difin, Warszawa.

Rakowska A., Sitko-Lutek A., (2000), Doskonalenie kompetencji menadżerskich, PWN, Warszawa.

Sajdak M, (2013), Innowacyjność jako niezbędna cecha zwinnego przedsiębiorstwa, [w:] Szynal J. (red.), Nauki o zarządzaniu Management sciences, Wydawnictwo Uniwersytetu Ekonomicznego we Wrocławiu, Wrocław.

Stoner J., Wankel Ch., (1994), Kierowanie, Państwowe Wydawnictwo Ekonomiczne, Warszawa.

Tokarski S., (2006), Kierownik w organizacji, Difin, Warszawa.

Trzcieliński S., (2011) Przedsiębiorstwo zwinne, Wydawnictwo Politechniki Poznańskiej, Poznań.

Witkowski S., Listwan T. (red.), (2008), Kompetencje a sukces zarządzania organizacja, Difin, Warszawa.

http://www.nieparzekawy.pl/baza-wiedzy/kompetencje-twarde-i-miekkie---co-to jest.html, [16.03.2015]

\section{MANAGERIAL SKILLS NEEDED MANAGERS OF THE XXI CENTURY}

Abstract: The subject of the discussion is management skills, which managers of the organizations of the twenty- first century need. Particular attention was paid to the universality of leadership skills, despite the fact that they have been created in different periods in which there was different economic situation. In this article were presented the most important management skills that managers of companies in the XXI century should have to be able to manage their organizations effi- 
ciently and effectively at that time. Leadership skills are an integral part of managerial positions, that's why every manager should have an extensive range of management skills, thanks to which will not expose the organization to unnecessary risk.

Keywords: management skills, managers, manage, skills, organization, company, 
